\title{
COMMUNAL AND INSTITUTIONAL TRUST: AUTHORITY IN RELIGION AND POLITICS
}

\author{
C.A.J. COADY \\ University of Melbourne
}

Linda Zagzebski's book on epistemic authority is an impressive and stimulating treatment of an important topic. ${ }^{1} \mathrm{I}$ admire the way she manages to combine imagination, originality and argumentative control. Her work has the further considerable merit of bringing analytic thinking and abstract theory to bear upon areas of concrete human concern, such as the attitudes one should have towards moral and religious authority. The book is stimulating in a way good philosophy should be - provoking both disagreement and emulation.

I agree with much of what she says, and have been instructed by it, but it will be of more interest and relevance here if I concentrate upon areas of disagreement. Perhaps they are better seen as areas, at least some of them, where her emphases suggest a position that seems to me untenable, but that she may not really intend. In that event, I will be happy to have provoked a clarification or the dispelling of my misunderstanding.

My focus will be upon problems in her account of communal authority and autonomy, especially with respect to religious and political authority. Here my worry is that she places too much trust in trust and not enough in what I call selective mistrust.

\section{THE EPISTEMOLOGY OF TESTIMONY: SOME PRELIMINARIES}

I have in the past written quite a bit on a topic central to Zagzebki's discussion, namely the role of testimony in our intellectual life, especially in my book Testimony: a Philosophical Inquiry. ${ }^{2}$ Moreover, the relation of

${ }^{1}$ Linda Trinkaus Zagzebski, Epistemic Authority: A Theory of Trust, Authority, and Autonomy in Belief (Oxford: Oxford University Press, 2012). References to this book will be bracketed in the text.

${ }^{2}$ C.A.J. Coady, Testimony: A Philosophical Study (Oxford: Clarendon Press, 1992). 
testimonial authority to autonomy was something I visited a little more recently in a paper on 'Testimony and Intellectual Autonomy.' I think that much of what I said there is congruent with Zagzebski's discussion of the way an individual's autonomy can be consistent with a certain deference to the authority of another's testimony and even of their beliefs revealed in non-testimonial fashion, but I detect a dissonance (to use one of her favoured expressions) between us when it comes to the authority of religious and political communities.

Where we agree is in rejecting what she calls epistemic egoism; a version of which embodies what J. L. Mackie once discussed as an ideal of autonomous knowledge built into the empiricist tradition, namely, the view that our wide-ranging dependence on testimony could only be admitted as knowledge or reliable belief if (to quote him) 'the knower somehow checks for himself the credibility of the witness' whenever he relies upon one. ${ }^{4}$ It is clear from the rest of the Mackie passage that 'checks for himself' means relying solely upon checks that use only the knower's individual resources and are quite independent of anybody's testimony. There are actually two possible interpretations of the egoism or individualism inherent in the tradition as Zagzebski makes clear in her book.

The first (what she calls 'extreme egoism') admits no role for the transfer of knowledge from others and restricts one's knowledge to what one can acquire solely by one's own individual epistemic abilities. This would, of course, lead to an extraordinarily narrow knowledge base for any person, though it is possibly what Plato had in mind in his comments on how testimony could not provide the logos that true knowledge (or understanding) requires. Interestingly, as Zagzebski notes, Elizabeth Fricker refers to this extreme position as 'intellectual autonomy', but what Zagzebski calls 'moderate' or 'standard' egoism and what I have called reductionism is more in tune with the tradition Mackie articulates, certainly in David Hume's discussion of reports of miracles. ${ }^{5}$ The extreme form is however still in play when people discuss moral autonomy since the idea that, in moral matters you must reach

${ }^{3}$ C. A. J. Coady, 'Testimony and intellectual autonomy', Studies in History and Philosophy of Science, Part A 33 (2):355-372 (2002).

${ }^{4}$ J. L. Mackie, 'The Possibility of Innate Knowledge', Proceedings of the Aristotelian Society, 70:245-257 (1969), p. 254.

5 David Hume, An Enquiry Concerning Human Understanding, section 10 'On Miracles', 2nd edition (Oxford: Oxford University Press, 1957). 
moral knowledge wholly by reliance upon your own resources has much more popularity. Zagzebski argues, correctly in my view, that there are serious problems with it, but I will not discuss moral knowledge directly.

I argued in my book that such egoism or reductionism about testimony was doomed to failure since it didn't take seriously the depth of our reliance upon the word of others. I criticised attempts to vindicate that reliance by recourse alone to individual sources of knowledge or reliable belief such individual perceptions, memories and inferences as doomed to failure. Not only were such attempts vitiated by impracticality (as H. H. Price had argued) because of the time-consuming amount of individual checking on the reliability of witnesses or other types of testifiers that the posture entailed, but most of the procedures that were apparently reliant only upon my unaided powers of observation, memory and inference were actually infected at core by further reliance upon unchecked interpersonal sources. The concepts of 'observation' and 'experience' that figured in such individualist efforts were invariably, at least in part, appeals to common experiences and observations rather than the individual's alone. Moreover, there were profound difficulties in determining the correlations between types of report and types of situation that the project required without again begging the question. Nor could the project be restricted to determining the reliability of this or that witness on this or that topic since what was required was a more general justification of, as it were, the institution of testimony. There is much more that could be said of this but I cannot say it here.

It is worth noting, however, that the widespread neglect of the topic of testimony that I originally complained of has been dramatically remedied and a debate between reductionist and non-reductionist theories has developed apace with much sophistication and complex distinctions on both sides. I do not intend entering this debate directly here, but I am unpersuaded that the egoist position has been restored by that debate. ${ }^{6}$

${ }^{6}$ Some important contributions in book form are: Jonathan E. Adler, Belief's Own Ethics (Cambridge MA: The MIT Press, 2002); Jennifer Lackey, Learning From Words: Testimony as a Source of Knowledge (Oxford: Oxford University Press, 2008); Jennifer Lackey and Ernest Sosa (eds), The Epistemology of Testimony (Oxford: Oxford University Press, 2006); and Paul Faulkner, Knowledge on Trust (Oxford: Oxford University Press, 2011). There are many other significant journal articles on the topic including Elizabeth Fricker, 'Telling and Trusting: Reductionism and Anti-Reductionism in the Epistemology of Testimony', Mind 104 (414):393-411 (1995); and Peter J. Graham, 'Testimonial Justification: Inferential or Non-Inferential?', The Philosophical Quarterly, 56 (2006), 84-95. 
The debate has encompassed other dimensions concerned with the moral or evaluative aspects associated with the attitudes of trust, acceptance, and mode of delivery involved in giving and receiving testimony. These have fed into a parallel philosophical movement that began in the 1980s investigating trust as a phenomenon and attitude in human affairs. The moral and epistemological aspects of trusting have been discussed by some excellent philosophers, many of them women, and most notably by Annette Baier. ${ }^{7}$ The epistemological aspect of this complex of investigations has often developed under the heading of social epistemology.

\section{ZAGZEBSKI'S POSITIVE ACCOUNT AND THE ROLE OF SELF-TRUST}

One issue that is nested in these discussions is that of intellectual or epistemic autonomy and its relation to authority. Zagzebski's account of this relation requires a version of anti-reductionism though her theory goes beyond reliance on testimony. Her theory is not content with showing the futility of the reductionist position, but argues for a nonegoist justification of our epistemic reliance on others and hence on the authority they have for us; this argument makes a positive virtue of beginning from the first-person perspective and from the idea of trust in the self. This strategy is interesting and original precisely because it recognizes some of the strength in the egoist's insistence on the importance of the intellectual standing of the self. There are two key ideas here. The first is that an individual's own epistemic base, the base that is to underpin epistemic autonomy, and is relied upon by the epistemic egoist, rests on nothing other than a form of trust - trust in the self's cognitive powers. So the very powers of personal observation, memory and inference are themselves inevitably taken on trust. This conclusion arises from the fact that there is a circularity in any attempt to justify an individual's basic epistemic resources since ultimately any such attempt relies upon those same resources. Many epistemologists, such as Richard Foley and William Alston, have recognised this, sometimes through consideration of the challenge of extreme scepticism and sometimes simply by reflecting upon the nature of rationality. Whether this resort 'refutes' scepticism or not, it is clear that it renders the attempt to use our reasoning powers

${ }^{7}$ Annette Baier has made numerous contributions to the trust discussion beginning with her influential article, 'Trust and Antitrust' in Ethics, Ethics 96 (2):231-260 (1986). 
to reject our reasoning powers curiously pointless for any endeavour to sketch the lineaments of our epistemological landscape. But Zagzebski goes further than this in arguing that the trust is not only forced upon us by the circularity, it is a requirement of another feature of our nature, or even a requirement of rationality, namely the need to reduce or eliminate dissonance. This dissonance operates at two levels. Since she thinks of rationality as 'doing a better job of what we do naturally' (p. 45) it requires self-reflection upon our natural inclination and apparent powers to seek truth. Awareness of the circularity creates a dissonance for the self-reflective person between trusting her natural epistemic faculties and believing that they are untrustworthy. It also creates a dissonance between the feeling that one's faculties are trustworthy and the feeling that they are not. The self-reflective person will need to resolve this dissonance as well. Compare the person who has every reason to believe that she has locked her house but has an obsessive doubt about it and not only returns home several times to check on it, but constantly feels that she ought through the rest of the day. ${ }^{8}$ It is possible to persist in such behaviour yet it is not only disabling, but clearly subject to the charge of irrationality. Such a charge is even more plausible where the dissonance is across the board of all one's natural epistemic powers. Hence, for Zagzebski, self-trust is a requirement of rationality. Further to this she argues that although self-reflection yields a rational trust in our faculties, it requires conscientious self-reflection in the use of those faculties to have a good chance of getting at the truth. As she puts it:

A conscientious person has evidence she is more likely to get the truth when she is conscientious, but she trusts evidence in virtue of her trust in herself when she is conscientious, not conversely. Her trust in herself is more basic than her trust in evidence, and that includes evidence of reliability. The identification of evidence, the identification of the way to handle and evaluate evidence, and the resolution of conflicting evidence all depend on the more basic property of epistemic conscientiousness. (p. 49)

Her next move is to generalise the trust involved to encompass trust in others. This requires a sort of universalising principle that has a Kantian flavour. Since I find that others have broadly the same epistemic capacities that I trust in myself I have no reason not to treat their situation as similar

8 This is a variation on an example of my colleague Karen Jones, cited by Zagzebski in the text. 
to mine with respect to self-trust and the exercise of conscientious reflection. So she thinks that consistency demands that 'I have the same basic trust in the epistemic faculties of all other persons whose general similarity to me I come to believe when I am conscientious' (p. 160). She thinks there is a prima facie case for the same conclusion with respect to moral beliefs. This leads to what she calls a weak form of epistemic universalism which she expresses as 'the fact that another person has a certain belief always gives me prima facie reason to believe it' (p. 58).

\section{SOME PRINCIPLES AND THEIR IMPLICATIONS}

Out of a great deal of close discussion of these matters she develops a variety of principles concerning more stringent justification of beliefs and emotions gained from others. I cannot explore all of this but a flavour of the principles in question can be gained from mentioning a few of them. First is one that makes a connection, as do several others, with the idea of authority and indirectly with that of autonomy. Consider:

\section{Justification Thesis 2 for the Authority of Belief (JAB 2)}

The authority of another person's belief for me is justified by my conscientious judgment that I am more likely to form a belief that survives my conscientious self-reflection if I believe what the authority believes than if I try to figure out what to believe myself.

It is noteworthy that this principle embraces more than justification of the testimony of others since what they believe may be shown in behaviour rather than explicit testimony. It is thus rather stronger than a testimony principle and perhaps more debatable since someone who seriously tells us that $\mathrm{p}$ is vouching for it in a way that their non-testimony behavioural manifestations of belief typically do not. This difference is important and is connected to Zagzebski's derivation of other-trust from self-trust, but I shall merely note it here, and will concentrate my criticisms mostly on areas where epistemic trust is in play in dealing with explicit religious (and political) statements of belief. ${ }^{9}$

${ }^{9}$ Her principle concerning trust in testimony is formally parallel to this trust in belief principle (though actually she has two formulations of both) and goes as follows:

'Justification Thesis 2 for the Authority of Testimony (JAT 2)

The authority of another person's testimony for me is justified by my conscientious judgment that if I believe what the authority tells me, the result will survive my conscientious self-reflection better than if I try to figure out what to believe myself'. (p. 133) 
It is also slightly puzzling that principle JAB 2 begins with phrase 'the authority of another person's belief' and concludes with a reference to that person's belief as 'what the authority believes'. This is puzzling as that person is not introduced as 'an authority' but simply as 'another person'. Since she thinks that any other person has some prima facie authority for us in their beliefs this may be all she means by calling any 'other person' an authority. But this is not the usual sense of 'an authority', nor is it quite the sense that she later relies upon. This is important for my later discussion of communal belief and communal authority.

Later she provides a community version of the principle that goes as follows:

Justification of Communal Epistemic Authority 2 (JCEA2)

The authority of my community is justified for me by my conscientious judgment that if I believe what We believe, the result will survive my conscientious self-reflection better than if I try to figure out what to believe in a way that is independent of US.

Several points of clarification are needed here. The references to 'we' and 'us' in the communal authority case is partly based on the common use of these pronouns to refer to communities to which individuals belong, but she takes this use to be a good indicator that the communities we belong to are what she calls 'extended selves'. She recognises that the forms of authority in such communities differ widely in those that have democratic structures to determine authority and those that are more top-down. She also recognises the fallibility of the extended self but argues that its imperfections are no barrier to the judgement that we do better at getting the truth by relying on the authority than by going it alone. If we make the conscientious judgement that the authority's record is so bad that we do better making the judgements without it then we need to transfer to another community or build a new community (p. 158). That we can reasonably reject an authority's belief (or testimony) is admitted by Zagzebski early in her discussion because it is a general trust in ourselves that leads to our trust in authority and that self-trust may be exercised to reject the authority's belief, if for example, I conscientiously judge that it is clearly inconsistent with other conscientiously determined beliefs.

She carries this apparatus of arguments and principles over to the discussion of moral and religious epistemic authority and touches upon political authority. In this endeavour she is committed to there being 
truth attainable in moral and religious matters and she argues for this commitment. Some, perhaps many, will dispute this, but I am going to accept it, partly because I believe it to be true, but mostly because I want to see whether what she makes of it in terms of authority is cogent.

Another of Zagzebski's important discussions concerns the role of emotions and of exemplars in the acquisition of knowledge. I cannot explore this fully here, but mention it at this point because of its relevance to some of her claims about religious, moral and political authority that I will criticise later. She holds that a conscientious person should trust her emotional faculties in the same way that she should trust her cognitive faculties since although there is no non-circular justification for the reliability of either yet the 'outputs of both can survive conscientious selfreflection' (p. 86). Of course some emotions do not match appropriately the circumstances in our lives but others can be judged appropriate by a self-conscious attempt to fit them to their objects. Amongst these emotions that can be trusted are indignation, sympathy, the feel for the ridiculous, and admiration. Admiration is significant in leading to the idea of exemplars. We can admire qualities and acts but also persons who display them, and we can and should learn from them. Zagzebski argues that this applies across the board to the intellectual, moral and practical qualities that are encapsulated in the concept of wisdom, until recently little explored by philosophers (pp. 81ff.). This learning from exemplars often involves a role for imitation.

\section{COMMUNAL AUTHORITY IN RELIGION AND IN POLITICS}

This account of Zagzebski's position is inevitably sketchy and oversimplified. I can only hope that it gives a fair understanding of her main line of thought sufficient to raise some issues about her account of intellectual autonomy and communal authority in religious, moral and political matters. In order to address that I will pass over difficulties raised by her argument from dissonance where, for example, one might question the strength of the need to resolve dissonance on which she relies so much, or the precise details of the consistency or universalisability argument she uses in the foundation of her theory, and so on. I think she can probably be defended against objections along these lines but I will not attempt that here. I will however say something about dissonance and the self in relation to trust in institutional authority. 
Her defence of authority in the epistemic arena is anti-reductionist in a way that, as we have seen earlier, runs counter to certain common ideological outlooks about authority and autonomy. I agree with her idea that, to put it in different terms, intellectual authority is not an external, as it were, regrettable necessity to be treated invariably with suspicion, but I think that her treatment of communal authority is unsatisfactory in certain respects. The idea of a community as an extended self has some obvious merits but the extension is rarely as straightforward as her treatment often suggests. The discourse of 'we' and 'our' is real enough, but the referent of these expressions is rarely straightforward. The nuances in such references are particularly complex in the case of political authority to which she does not pay a lot of attention. A political community is invariably composed of sub-communities that are either directly political themselves, as with political parties, or communities devoted in the first place to ends other than the political but with interests, values and beliefs that bear upon the political and drive political thinking. So an individual's extended self is likely to be extended in several different, potentially clashing directions. A person who sees herself as a member of the mining community, the Anglican church, the aboriginal community, and her small township is likely to have respected exemplars in each of these 'extended selves' and will often have to do some strong negotiating to avoid a schizophrenic 'extended self'. Zagzebski links her discussion of epistemic authority to the project that an 'executive self' has of harmonising her desires, emotions and beliefs in pursuit of fulfilment, and there is much to be said for this. But the executive self who self-reflectively examines this situation will have to come to terms with clashes internal to her community. This will often enough involve admiration for different authority figures with different key beliefs amongst some or many overlapping beliefs. Some of these will be contemporary figures and others figures from the near or distant past. Before looking further at politics, I want to examine what she says about religious communities with the above discussion as background because, in addition to the intrinsic interest of religious authority (and autonomy), there are certain parallels between religious and political communities.

A cautionary note is that Zagzebski, in discussing the shortcomings of Joseph Raz's definition of political authority as a model for authority more generally, concentrates on small communities which suggests that she has some misgiving about extending the account she develops 
regarding them to larger political communities. It is I think more likely that she focuses on small communities to show more readily her differences with Raz rather than as a sign that she cannot extend her account more broadly, since she finishes with principles of justification of communal authority that contain no such qualification about small size, and in any case small communities are often composed of smaller communities again with similar problems to those I have hinted at. Moreover, she later applies her principles to huge communities like the Catholic Church, so it seems size is not a reasonable differentiating factor. She says some other things about Raz and political authority that invoke something different and I will return to that.

When Zagzebski discusses religious epistemic authority she notes that different religions have evolved very different structures or techniques to convey or exercise communal authority and these range from highly formal edifices like the 'teaching office of the Catholic Church' (p. 176) to the informal immersion in a way of life like the Old Order Amish. I think the contrast here is not as sharp as it appears, but the Catholic community, tradition and teaching authority is in any case understood by Zagzebski in too monolithic a fashion, admittedly a fashion encouraged by the institution's formal leadership. Within any existing community of knowledge or belief, including religions, there will be various sub-communities sharing some respect for the authority of other subcommunities, but differing from them in important ways, and similarly there will be different exemplars favoured by different members of such sub-communities. Think, for instance, of the philosophy community within a country or even within a particular university.

In speaking of the way that we accept or reject communal authority, Zagzebski appears, at least some of the time, to think of it as an all or nothing affair in what seems to me an unrealistic way. She admits, as we saw earlier, that if we make the conscientious judgement that the authority's record is so bad that we do better making the judgements without it then we need to transfer to another community or build a new community (p. 158). But an autonomous self in a religious community negotiates its membership and its shared beliefs in a much more dynamic and interactive way than this picture suggests. To take the example of the Catholic Church: its highly authoritative structure and the edicts of its official leadership have often in the past been at odds with widespread beliefs of sections of the faithful and continue (even more dramatically) to be so today. The great degree of this rift is evident in both doctrinal, 
moral and 'disciplinary' matters as is evidenced by a variety of polling figures of ordinary Catholics' beliefs about the morality of contraception, homosexuality, divorce, abortion, the doctrines of hell and 'no salvation outside the Church', and the disciplines of clerical celibacy and an exclusively male priesthood. ${ }^{10}$ Gallup Poll figures in 2009 showed that 40 percent of Catholics in the USA (compared to $41 \%$ of non-Catholics) found abortion 'morally acceptable." ${ }^{11}$ Nor can this sort of result be put down to simple lay ignorance or backsliding since the rift is also present amongst regular lay churchgoers and similar disagreement is evident amongst clergy and theologians. For instance, even among those who attend church once a week or more, 83 percent of sexually active Catholic women use a form of contraception banned by the Vatican. ${ }^{12}$ Such divergence has sometimes led to splintering and the formation of new communities or departure from religious community altogether, and that fits Zagzebski's picture. But it has also been contained within the community so that quite different positions on what it is necessary to believe have been maintained without splitting the 'We' and 'Us' extended selves. ${ }^{13}$ How can this be?

One way of dealing with this is to distinguish between core and peripheral beliefs, and argue that as long as the core beliefs are centrally authoritative for the community members, there is room for diversity on the others. This distinction has some merit, but determining the division between what is core and what is peripheral is often enough something

${ }^{10}$ Just some of the recent evidence from respectable polls can be found (for the United States) in regular reports in the journal Catholics for Choice. For a summary of findings see: Catholics for Choice. (2011). The Facts Tell the Story, Catholics and Choice, Washington DC: <http://www.catholicsforchoice.org/documents/Factstellthestoryweb. pdf $>$ [accessed 30/01/2014]. Recently, in the UK, the sociologist, Professor Linda Woodhead, conducted a poll (administered by YouGov) that reported similar findings. See http://faithdebates.org.uk/research/. For Woodhead's own summary of the research see her essay, 'New Poll: "Faithful Catholics" an Endangered Species', in Religion Dispatches, January 20, 2014. Available at: <http://www.religiondispatches.org/archive/ culture $>$ [accessed 25/11/2014].

${ }^{11}$ See: <http://www.gallup.com/poll/117154/Catholics-Similar-Mainstream-AbortionStem-Cells.aspx $>$ [accessed 30/01/2014] .

${ }^{12}$ Catholics for Choice, 2011.

${ }^{13}$ An interesting example of tolerated dissent within the wider Catholic community on an important issue is the fierce and unresolved dispute between the Jesuits and Dominicans in the 16th and 17th centuries about the nature of grace and its relation to free will. This was an issue at the heart of theological controversy leading to the Catholic/ Protestant split in the Reformation, so its failure to disrupt Catholic unity in this later period is instructive. 
that authority will want a say upon, and it is often enough, precisely that 'say' which is contested. Moreover, 'peripheral' need not mean unimportant; it may signal merely that the issue is not one on which authenticity of one's membership in the community should turn. In the case of the Catholic Church, for instance, it seems to me as a Catholic (and of course to others, Catholic or not) that the ordination of women priests is such a peripheral matter, as is the celibacy of the clergy. Yet the formal 'teaching office' sees things differently.

\section{THE COMPLEXITIES OF INSTITUTIONAL AUTHORITY}

This raises the question of institutional authority. Communities seem inevitably to generate their distinctive institutions, and these equally inevitably make claims to a certain authority both practical and epistemic. The practical dimension can be more or less coercive, but always involves power of some sort. That is very characteristic of politics, but exists elsewhere.

The question of power returns us to the ambiguity about the nature of the authority of others that I noted earlier in Zagzebski's expression of Principle JAB 2. The fact that each person has some presumptive authority for others about their beliefs (if it is a fact) is different from the authority that designated 'authorities' have for their beliefs in certain areas. We can assume that ordinary folk usually have the expertise that goes with the normal operation of their cognitive faculties, broadly construed, and that gives their beliefs what authority they have for others, but those we honour with the title 'expert' or 'authority' have special skills or status that require a further explanation. The existence of such authorities is often connected with institutions rather than communities simpliciter. In both, epistemic authority can be exercised, formally in the one and less formally in the other, though there is an interaction between the two that can take positive or negative forms, involving either endorsement or opposition.

Zagzebski does not discuss institutional authority directly but it is something that brings a political dimension into the discussion of authority and autonomy in even the most relaxed, informal community contexts. It also, I think, provides more room for a degree of epistemic and practical caution to operate concerning the exercise of authority that goes beyond what Zagzebski usually allows. In the case of religion this means that there is room for tension as well as support between 
what we might call a wisdom dimension and an institutional dimension to community authority. This relationship also calls into question any attempt to think of the authority of 'we' or 'us' in isolation from epistemic authority residing outside that community.

Zagzebski has an interesting discussion of wisdom and she points out correctly that it has, until very recently, received scant attention amongst contemporary philosophers. Recognition of wise people involves ceding a degree of epistemic authority to their views, but the institutional leaders of a religious community are not invariably wise people so that a tension may readily arise between their authority and that of the exemplars of wisdom in the community. The same is true, perhaps more acutely, of political authority. Short of wisdom, we can expect that communal authorities have some knowledge of areas relevant to their authority, indeed that is bound up with their being epistemic authorities, but where they occupy positions of institutional authority, it may become apparent that they lack not only wisdom but even the relevant knowledge. They also view themselves as guardians of the integrity of the institution and they are invested with the formal powers that go with institutional office. These facts expose them to the temptations of power and selfrighteousness, and to the temptations of placing the need to 'save face' for the institution above the demands of justice (including epistemic justice - a topic discussed by Miranda Fricker) and accountability. ${ }^{14}$

A striking illustration of these dual temptations is provided within the Catholic Church by the alarming extent of clerical sex abuse of children as well as the 'Magdalene' incarceration and brutalising of young women in certain Irish convents (and elsewhere). ${ }^{15}$ These tragedies were compounded by the appalling behaviour of the clerical authorities engaging in concealment, disingenuous denials, lies, and cover-ups when responding to information about those practices. Some of this involves the abuse of practical religious or political authority, but quite a lot of it involves the abuse or failure of epistemic authority, since the victims and the wider Catholic community trusted the clerical leaders to know what was right in doctrine and morals, to tell the truth about

${ }^{14}$ For Fricker's interesting views, see Miranda Fricker, Epistemic Injustice: Power and Ethics of Knowing (Oxford: Oxford University Press, 2007).

15 The horrors of these convent practices have recently been dramatised in two films 'The Magdalene Sisters' and 'Philomena'. I cannot vouch for the detailed accuracy of these films, but there is little doubt about the factual situation from which their fiction (or 'faction') is derived. 
how they acted on it, and to receive information in good faith. Where the abuses were not simply the result of outright vice and hypocrisy, as the individual sexual offences had been, the cover-ups and lies were often justified at the time by beliefs about the need to preserve the authority and reputation of the institution. In addition, the maltreatment of the women 'sinners' and their babies, for instance, were sometimes justified by authoritative religio-moral teachings about sex, about punishment for sin, and more broadly about extra-marital parenthood. Some of these beliefs were of course shared not only with many rank and file Catholics at the time but also with many in the wider community in Ireland and elsewhere. The involvement of parents and the Irish State in the Magdalene scandal supported the Church's role. Yet this itself really highlights some of the difficulties in isolating the religious authority of one community (whether epistemic or practical) from that of others.

The Catholic Church is not indeed unique in having such abuses perpetrated by its office-holders, and having higher authorities spurn the victims, protect the offenders, and guard the institution's reputation with secrecy, subterfuge and outright lies. On the list of abusive institutions investigated by the Australian Government's current Royal Commission on institutional sex abuse are: The Salvation Army, Scouts Australia, the YMCA, and an Anglican children's home. As this list shows, the problems are not restricted to religious institutions; besides the Scouts and the YMCA in Australia, in the UK the BBC and numerous public hospitals have been investigated by the police and other public bodies about their roles in the entertainer Jimmy Savile's ghastly depredations against young people over a period of 40 years.

A further feature of the clerical sex-abuse disaster is the degree to which the failures were abetted by reluctance to believe that members of the priestly fraternity were capable of such crimes. It is hard to know how much this factor worked with the authorities themselves, but, amongst other things, the reluctance indicates an excessive personal and epistemic trust (especially by parents) in the authority of religious leaders.

\section{THE AUTHORITY OF 'EXTERNAL' COMMUNITIES}

This brings us to another aspect of communal identity and the extended self which is that any given person is a member of many, often very different communities, external to the community in question and its sub-communities. And even when not directly a member of other 
communities the knowledge held in those communities can be accessible to outsiders and relevant to their communal beliefs. So, in the case of religion, especially historically-oriented religions like Christianity and Islam, which are also religions of a book, the understanding of that religion's beliefs (core or otherwise) can be affected by knowledge or belief gained in scholarly communities such as those of history, philosophy, science and linguistics. Deference to the authority of such communities must have some impact for what survives the conscientious self-reflection of any member of the religious community.

In rejecting epistemic egoism, Zagzebski nonetheless insists that the autonomous self must be able to subject her reliance upon particular beliefs gained from authorities to 'critical self-reflection' (p. 228). Unlike epistemic egoism, this critical stance does not eschew all recourse to authoritative testimony nor accept only that which it can independently verify by its own individualistic resources, nor reject a role for emotion or the exemplary. But this means that it is not rigidly bound by its adherence to particular communal authority. I think Zagzebski does and should accept this much. But my argument goes further because I want to say that the communal authority itself is similarly open to such critical self-reflection and that opens the prospect of belief revision at the communal and institutional level as well. So the individual's rejection of some community belief or (in the institutional case) some official teaching may count as an effort to revise the community's self-conscious reflection and its results rather than, as Zagzebski usually puts it, a rejection of the community and its authority. Just when such revisions count as a rejection of what the community stands for or reveal a more authentic understanding of its reality is a difficult question, but it cannot be taken for granted that every such revision is a rejection. Consider the Irish child abuse scandals: Zagzebski's option of departure from the community is certainly one possibility, indeed it is the one which so many Irish Catholics have taken, but their departure is something the institution and many who remain in the Catholic community deeply regret. Not only that, but others, who are equally outraged by the beliefs and performance of the authorities, have stayed in the community vowing to reform the attitudes, beliefs and even structural features of the institutional authority, partly because of the role they regard these as playing in the scandals discussed briefly above.

A further illustration may be drawn from the history of Christianity. Christian unity was shattered in 1054, partly by a dispute about the 
nature of the Trinitarian understanding of God. The Eastern churches split from the Roman churches over what is called the 'filioque' clause (in English, 'and the Son') in the version of the Creed called Nicene, though the phrase was not used at the Council of Nicea in 354 but adopted at later Councils. The amended Nicene Creed, after treating of Christ as sharing in the Divinity as the Son then proclaims: 'We believe in the Holy Spirit, the Lord, the giver of life who proceeds from the Father and the Son.' The Eastern churches rejected this since they held that the Holy Spirit and the Son both directly proceeded from the Father. This was a major doctrinal issue behind the Great Schism which created the Orthodox church traditions of the East as separate from Rome. Of course there were other issues, both theological and non-theological, as there always are. Many of these were political or quasi-political and I will say more of the role of the political later. But that differences over this wording should have had such momentous community consequences strikes me as amazing. I cannot understand why such an abstruse technicality as the difference over such 'proceedings' could be given a religious significance of this sort. I can understand how it might exercise a certain sort of theological and philosophical mind, but it seems to me irrelevant, hardly even reaching the peripheral, in terms of what matters in the Christian message. If the Nicene doctrine is a defining belief of the communal authority of the Church (not just the Catholic Church but most Protestant churches too) then critical reflection that rejects it or its importance surely calls for a change in what is of defining importance for membership rather than for change of community. It is, I think, significant that the other crucial Christian Creed in favour with most Christian denominations, including Catholic and some Orthodox, is the more ancient Apostles' Creed which makes no mention of internal relations within the Trinity.

I put this objection, probably not clearly enough, to Linda Zagzebski when she gave the lectures from which this book developed in Oxford in 2012. In the book, she addresses it in the context of a section on the need to resolve dissonance caused within a community by the fact that some other community which shares some of the first community's crucial beliefs also has a range of important conflicting beliefs that have for them survived conscientious self-reflection. She instances Christian and Moslem differences over the nature of God - Christians believing in the Trinity and Moslems rejecting that account in favour of a simple Unity. In response, she enunciates a Need To Resolve Conflict Principle as follows: 'It is a demand of rationality for a community to attempt 
to resolve putative conflicts between its beliefs and the beliefs of other communities.'

She thinks that such conflicts may be resolved in various ways, such as changing some of our beliefs, or 'by adding a belief that explains why the dissenting community is mistaken, or by modifying the belief that conflicts with the belief of the other community in a way the members of the other community would not accept but which resolves our own dissonance' (p. 225). She also thinks that the fact that different communities have arrived at beliefs (perhaps different from our own) by conscientious reflection on the trustworthiness of those beliefs can in principle be recognised by each community and hence arises the possibility of advance in removing dissonance by inter-community dialogue.

This discussion of disagreement between communities is clearly relevant to some of my earlier comments and I will address it shortly. First, I want to see how it relates to the filioque issue and its role in the Great Schism. Zagzebski says that 'few theologians now consider it worth so much fuss' and concludes that the degree of the need to resolve dissonance within a community 'depends upon the degree of dissonance created within a community by the conflict. The degree to which a community cares about a belief is one dimension affecting degree of dissonance' (p. 225).

There are several things to say about this. The first is that the idea that 'few theologians now consider it worth much fuss', if true, as it may well be, needs to be set against the fact that the phrase and the doctrine it represents remain in the Nicene Creed which is recited daily in the Catholic Mass and other Christian denominational services. In so far as the amended Nicene formula, which include this account of 'the procession' of the persons of the Trinity, define what the Catholic and many other Western Christian communities believe then it seems they continue to care. In fact, the recitation may not have much if any cognitive and psychological resonance today, but then it is unclear how much the Western Christian communities cared about this in the $11^{\text {th }}$ century. Many theologians cared, it seems, and apparently the Papal and Byzantine church and secular authorities cared, but we don't really know how the Catholic faithful felt. In any case, the question is whether all of them should have cared enough to split the Church.

The significance of the filioque clause is probably less doctrinal than political. The split of 1054 had been brewing since six centuries or more 
as a conflict of power and authority between Rome and Constantinople. It embraced theological and liturgical issues as well, including the role of statues and icons, the use of unleavened bread in the Eucharist, but very prominently the primacy of the Pope in Rome. Serious historical research makes it plain that political motivations both within the religious institutions and in the wider political world played a major part in creating the widening gulf between the East and West even where they continued to have much in common doctrinally, and also impeded several genuine attempts at reconciliation. ${ }^{16}$ It would be a mistake to discount sincere religious motivations, but also to discount the role of political motivations, since the two are often entwined.

If this is right, and I cannot marshal the evidence to support it fully here, then it illustrates the way that the institutional epistemic authority of a community is subject to scrutiny from within by those of its members who have reflected on a spectrum of considerations drawn from communal authority elsewhere which the conscientious self can (and perhaps must) attend to in its reflection on its trust in the institutional authority regarding community beliefs. So, understanding the history of the political and cultural forces at work in the controversy over 'filioque' can help the conscientious self determine whether this aspect of Trinitarian doctrine is or should be a crucial element of community belief. I have instanced here the role of historical authorities, but similar things could be said of biblical scholarship which has had an enormous impact on the way many Christians understand their faith today. Zagzebski gives one example of this about the accuracy of the Acts of the Apostles, but there are other cases more directly affecting doctrinal beliefs. Of course, there are various problems with the methodology of biblical criticism and there are sharp divisions within its ranks, a feature it shares with other disciplines in the Humanities. There are also, as Zagzebski notes, questions about whether some of the scholarly conclusions reflect prior metaphysical commitments that prejudge the evidence or whether the evidence independently supports those metaphysical views, for example,

${ }^{16}$ A good account of these political and religious factors can be found in Diarmaid MacCulloch, A History of Christianity; the First Three Thousand Years (London: Allen Lane, 2009). See especially Ch. 9, Part 1, and Ch. 10, Part 4. MacCulloch and other historians stress the political role played by the Emperor Charlemagne's conflict with Constantinople in bringing the matter to a head, even though at the time Pope Leo III refused to make the phrase part of the liturgy in Rome. This inclusion did not occur until the $11^{\text {th }}$ century. 
in the acceptability or rejection of miracles. But this merely emphasises the complexity of the materials that conscientious reflection must take into account.

\section{POLITICS, CORRUPTION AND INSTITUTIONAL AUTHORITY}

Another complicating factor in the case of institutional authority concerns the facts of corruption, especially the corrupting influences of power. Acton's famous dictum that 'all power tends to corrupt and absolute power corrupts absolutely' contains an insight into the temptations of institutional leadership and its authority that has been conspicuously vindicated by history. The more that the power of authority is centralised, not subject to close scrutiny, and remote from the desires, needs, and insights of those subject to it, the more its exercise can be distorted by aims inimical to the communal purposes which give it legitimacy. This is as true of the epistemological aspects as of the practical. The modern movement towards political democracy and its constitutional protection of citizen's rights against the abuse of power arises from an understanding that is indebted to the force of Acton's dictum.

In discussing Raz's account of political authority, Zagzebski comments that he has devised it as a contribution to the literature on political freedom within the framework of political liberalism, and she interprets this to mean that his account is constrained by a desire to maximise political freedom and to minimise political authority. She says that this perspective requires that it is more important to devise an account of authority that prevents tyranny than to give the bearer of authority the function of assisting the subjects in pursuing their individual and collective good' (p. 140). Consequently, she surmises that 'most modern political thought is motivated more by fear of bad authority than by desire for good authority' (p. 140). She gives no verdict on this liberal project, but insists that epistemic authority is different in that the oppression that the liberal political project aims to forestall rarely applies in the epistemic area, and hence Raz's liberal constraints are 'not important' for her project.

There may be some point in this dismissal for cases of non-institutional epistemic authority or even lightly institutionalised such authority, but once one realises that the exercise of most institutional authority involves considerable power vested in the authorities then the room for exercise 
of that power in misguided, oppressive and corrupt ways is present, and the realisation of that fact raises a question both about the degree to which the authority has been distorted by these temptations and about the relevance of that answer to the trust to be given to the authority's claims, including knowledge claims. ${ }^{17}$

In the case of political authority, different people will no doubt answer these questions differently, but the widespread mistrust of politicians, even in liberal democratic societies, testifies to the verdict that most citizens have arrived at, and there is a considerable weight of history, not to mention the evidence of contemporary whistleblowers, on their side. This degree of mistrust is often lamented by commentators (and of course by politicians) and is said to impede good government, but it is unclear that more unqualified trust would remedy the situation. ${ }^{18}$ Structural changes in the forms of authority and its implementation are more likely to lead to greater trust, though they may of course require trust in some authorities to devise them and to bring them about. Zagzebski's claim that most modern political thought is motivated by 'fear of bad authority than by desire for good authority' poses a false opposition since the desire for good authority should imply a fear of bad authority and the latter can motivate alertness to and respect for the former.

In the case of religious authority, it seems to me that points similar to the political 'constraints' apply as well. Indeed, the liberal and democratic spirit that informs the caution about political power and its relation to the individual's freedom should, it seems to me, also inform a similar caution about other forms of institutional power, including that in the area of religion whether the exercise of that power is practical, moral or epistemic. To return to the illustration of Catholicism, the present

17 These distortions in the area of knowledge are often assisted by the control that political authorities exercise directly or indirectly over the language of communal discourse. Consider, for example, the way that the term 'enhanced interrogation techniques' has gained currency, especially in the United States, in the discussion of torture. Our enemies ('they') commit 'torture' where 'we' engage in 'enhanced interrogation techniques'.

18 Political theorists have been much exercised by the nature of trust in political authority and institutions, the extent (if any) of its decline, and whether any such decline is a good or a bad thing. Notions like 'social capital' and 'civil society' are often bandied about in this connection, and often confusingly so. For good discussions of the complex problems in this area see: Mark E. Warren (ed.) Democracy and Trust (Cambridge: Cambridge University Press, 1999). Unfortunately, space precludes a recourse here to the insights of this debate. 
Catholic structures of authority are still modelled on just those autocratic forms of political authority towards which the liberal project developed such well-justified suspicion. Those forms, I would argue, are ill-conceived in terms of a Divine mandate to maintain them at all costs, and it is interesting to see that Pope Francis is impatient with many of them, as so many ordinary Catholics have already become. But none of this is to say that the only resort for religious people is some form of epistemic and practical egoism. There remains a place for authority in religion, whether epistemic, moral and practical, and it will resemble the pattern of trust that Zagzebski so carefully and subtly develops. But it will have more stress upon the exemplary authority, it will require a more complex picture of community authority, and, while admitting the necessity of communal institutions, it will have what we might call both selective trust and selective mistrust in their operations and their office holders.

Zagzebski laments the 'disastrous effects' of the general decline of trust in authority in modern life and the denial of a role for authority as a condition for human fulfilment. She sees her book is an attempt to restore that trust in a modern form (p. 254). Yet such a modern form must admit that there are many areas of our lives where we rightly moderate the trust we give on the basis of knowledge we have gained from trusted others, for example, the cautionary trust many of us have in real estate agents and used car dealers, and yet this need not give ammunition to general epistemic or emotional egoism. So, a degree of selective mistrust for institutional authority, whether political, religious or moral, may be precisely what the executive self in its conscientious deliberations is rational to adopt. Whether the conscientious self adopts this stance will partly depend upon local facts available to that self, concerning, for example, the record of specific institutions, but is also likely to be influenced by broader political and social outlooks that themselves reflect both personal interests and experiences and also trust in sub-communal extended selves and exemplars. Consider the institution of policing. In liberal democratic societies people in comfortable circumstances and with dominant interests within the society that are mostly supported by the status quo tend to have an unqualified trust in the police institution, whereas the poor and disadvantaged tend to treat the representatives of that institution with more qualified trust. These sub-communities will tend to have quite different responses to complaints of serious police misbehaviour and to police denials of the allegations. The reactions 
will be even more polarised where the sub-communities differ in racial or ethnic composition. ${ }^{19}$ Of course, sound policing can be a crucial element in establishing and maintaining the rule of law and the security of citizens, but the opprobrium of the term 'police state' shows the potential downside of the institution and hence the need for caution about wholehearted institutional trust in this instance.

The idea of selective mistrust may however be thought to create a particular problem for a non-reductive analysis of our reliance upon the institution (as it were) of testimony. In particular, advocates of that analysis (or better, family of analyses) often point to the deep role of noninferential trust in testimony that exists, necessarily, it seems in young children. Such children develop a framework of language and its concepts, and a basic set of reliable beliefs from parents and other adults early in life without which they could advance no further epistemically. It seems that this important stage proceeds with no recourse to anything like selective mistrust. But there are two comments to make on this. The first is that, as Thomas Reid insisted, this early state of tutelage is a preliminary to later stages that have a more sophisticated critical dimension, and it is then that selective mistrust plays a significant part. Reid says that our immature judgement 'is almost entirely in the power of those who are about us in the first period of life. If children were so framed as to pay no regard to testimony or authority, they must, in the literal sense, perish for lack of knowledge'. He goes on to say: 'But when our faculties ripen, we find reason to check that propensity to yield to testimony and to authority... , , adding, that nonetheless 'the natural propensity still retains some force. ${ }^{20}$ Second, the picture of even very young children as totally passive epistemically in the face of adult testimony is, in any event, an unrealistic one, as most parents realise and much empirical work confirms. Quite young children ask for explanations, realise that some things they are told contradict others, and occasionally find that they have been misinformed where one informant testifies contrary to another. So, although their reliance on testimony goes very deep and helps indicate its significant role in adult life, thereby offering support

19 The asymmetry of generalised trust in political institutions between groups with high socio-economic status and those with lower SES is argued for by the sociologist Orlando Patterson in his 'Liberty against the democratic state: on the historical and contemporary sources of American distrust', in Warren, op. cit., p. 196.

20 Thomas Reid, Essays on the Intellectual Powers of Man, Derek Brookes (ed.) (Edinburgh Edinburgh University Press, 2002), Essay VI, Chapter V, section 10. 
to the non-reductionist thesis, the example of early childhood learning also shows the incipient presence and emergence of selective mistrust. ${ }^{21}$

My remarks about religious and political institutions and the idea of selective mistrust suggest that the crucial concept of self-trust that Zagzebski employs so effectively may also need qualification, or, at least, further clarification. The complications of the extended self are less conspicuous for the individual self, but they are not entirely absent. Modern psychology has made much of divisions within the self, but they were also known to the ancients. Zagzebski realises there can be dissonance within the conscientious self and makes the need to resolve it a significant element in her project. But it is also characteristic of personal growth not only to seek the resolution of dissonance in our beliefs, but to discover the possibilities of mistrusting oneself: the healthy exercise of our cognitive and emotional powers should lead to the realisation that these capacities are not only essential to navigating our world and flourishing in it, but also prone to lead us astray in a variety of ways. Indeed we might say that the capacity for trust requires the robust capacity for (selective) mistrust as its other face. ${ }^{22}$ This may lead to trusting others more than we trust ourselves, but it may also lead to seeing that some trusted authorities have been led astray by forces and defects we have recognised to mistrust in ourselves. These misled authorities may well be those of (one of) our own communities and its institutional leadership, and insight into this, and the tendencies contributing to it, may come from our trust in authoritative knowledge gleaned from communities quite outside our own, as well as those in other communities to which we belong.

${ }^{21}$ For samples of recent empirical work on the relevant capacities of very young children, see: 'Preschoolers' Search for Explanatory Information Within Adult-Child Conversation', Brandy N. Frazier, Susan A. Gelman, and Henry M. Wellman, Child Development, Vol. 80, No. 6 (2009), 1592-1611; and Paul L. Harris and Melissa A. Koenig, 'Trust in Testimony: How Children Learn about Science and Religion', Child Development, Vol. 77, No. 3 (2006), 505-524. My thanks to another (to me anonymous) contributor to this volume for raising the issue of child testimony in a comment on this chapter. My thanks also to Margaret Coady for alerting me to the scholarly literature on the critical capacities of young children.

${ }^{22} \mathrm{I}$ am indebted for this thought to a comment by Karen Jones on an earlier draft of this paper. 